\author{
Ана С. БАТАС ${ }^{*}$ \\ Филолошки факултет \\ Универзитета у Београду
}

\title{
НАЧИНСКА ОБЕЛЕЖЈА У СРПСКОМ ЈЕЗИКУ
}

\begin{abstract}
У овом раду бавимо се начинским дистинктивним обележјима (континуираност, одложено уклањање, стридентност, назалност и латералност) и њиховом применом у матрицама фонема српског језика.
\end{abstract}

Кључне речи: фонологија, дистинктивна обележја, начинска обележја, српски језик

\section{1. Увод}

1.1. У раду се бавимо једном врстом (дистинктивних) обележја (у даљем тексту ДО или обележје) која фонолози углавном сврставају у начинска и разликују их од обележја која су у вези са местом артикулације, као што су обележја короналност, лабијалност, дорзалност, антериорност ${ }^{1}$ и сл., али и од обележја која су у вези са главним класама гласова (фонема) $)^{2}$, као што су обележја консонантност, сонорност, апроксимантност и сл.

1.2. Летимичним погледом на литературу коју у раду користимо, види се да је већина радова, било србистичких, било страних, настала у другој половини 20. века. У раду не пружамо нову интерпретацију ДО, па се чак не бавимо ни њиховим местом у хијерархијској структури, што је чест предмет проучавања савремених нелинеарних фонолошких теорија. Намеће се самим тим питање зашто се онда овим предметом бавимо. Два су основна разлога. Први од њих произилази из огромних и тешко премостивих разлика у интерпретацији ових обележја у домаћим радовима, који су безмало сви настали

\footnotetext{
*anabatas@fil.bg.ac.rs

${ }^{1}$ Обележјем [короналност] и сродним обележјима бавили смо се у раду Батас 2018, а преосталим обележјима тек планирамо да се бавимо.

${ }^{2}$ Обележје главних класа представља било које дистинктивно обележје које се користи да подели сегменте у „главне класе”, као што су опструенти, сонанти, вокали, назали, ликвиде и глајдови (Траск 1996: s.v. MAJOR-CLASS FEATURE; наш превод).
} 
под утицајем једне фонолошке теорије. Други разлог јесу новије дефиниције и интерпретације обележја. Фонолошке теорије ДО доживеле су процват осамдесетих и деведесетих година прошлог века, али нису оставиле трага у домаћој литератури.

1.3. Теорија дистинктивних обележја Р. Јакобсона, М. Халеа и Г. Фанта (у даљем тексту ПСА), заснива се превасходно на акустичкој природи обележја. Р. Јакобсон је на разним местима често истицао да је акустичка природа сегмената ${ }^{3}$ неупоредиво значајнија од артикулационе. Ова теорија је више од свих осталих утицала на домаће радове (и сербокроатистике и србистичке и кроатистичке $)^{4}$ : Јакобсон 1949/1964, Муљачић 1964, Брозовић 1968, 1971, Симић-Остојић 1996, Барић et al. 1997, Петровић 2000, Петровић-Гудурић $2010)$, па су из тог разлога у поменутим радовима присутне све предности и мане ове теорије (о томе више у т. 1.4). На савремене фонолошке теорије највише је утицала монографија Н. Чомског и М. Халеа (у даљем тексту СПЕ), која се заснива превасходно на артикулационим особинама обележја. Када се у савременим радовима и уџбеницима упућује на традиционалну генеративну фонологију, мисли се управо на ову монографију Н. Чомског и М. Халеа. О начелним разликама између ове две теорије (ПСА и СПЕ) дискутовано је у бројним научним радовима, монографијама и уџбеницима, па се у овом раду нећемо упуштати у општепозната разматрања. Да артикулационе карактеристике обележја нису заувек превладала акустичке, примери су новији радови као што су нпр. Флеминг 2002 или Бурсма 1998.

1.4. Након традиционалних фонолошких теорија, укратко представљених у претходној тачки, које једним именом можемо назвати линеарне фонолошке теорије, појавили су се новији приступи са циљем да се уклоне неки недостаци претходних теорија. Појавила се, пре свега, аутосегментална фонологија, која се заснива на становишту да постоје различити редови (tiers) фонолошке репрезентације и да се помоћу њих могу приказати појаве које се протежу на више од једног сегмента. Првобитно је замишљена да се њоме опишу прозодијске (супрасегментне) појаве, али су се у каснијим радовима као предмет нашле и оне сегментне појаве које се протежу дуж више сегмената (фонема, слогова), као што су консонантске и вокалске хармоније (више о најзначајним радовима аутосегменталне фонологије в. Клементс-Хјум 1996). Други недостатак линеарних приступа ДО, по речима Н. Клементса и Е. Хјум (1996: 182), огледа се у непостојању хијерархије међу обележјима и немогућности да се она групишу у категорије блиске традиционалној фонетици, као што су место и начин артикулације. Клеметс и Хјумова посебно истичу значај радова Н. Трубецког, у којима се јављају зачеци идеје да се обележја могу груписати у „природне класе”.

Са овом се констатацијом само делимично слажемо, зато што се у великом броју радова, почев од ПСА, осим позитивног и негативног

\footnotetext{
${ }^{3}$ У раду често користимо „сегмент” тамо где не желимо прецизирати да ли се неко обележје односи на фонеме или на алофоне.

${ }^{4}$ Без обзира на разлике које постоје у српском и хрватском стандарду, сматрамо да се матрице ДО не разликују.
} 
(пред)знака остављају празна места у пољима матрица или се уписују „нуле”. То значи да су и линеарне матрице заправо тродимензионалне, јер се управо изостанком знака (или уписивањем „нуле”) у „трећу” димензију пројектује повезивање фонема у групе. Покушаћемо да то боље објаснимо на примерима.

(1) Р. Јакобсон (1949/1964) опонира преко обележја назалност - оралност назалне сонанте и звучне експлозиве (фонему /d/ тумачи као експлозив), а оставља празна места у за све остале фонеме (в. табелу 3). То значи следеће:

a) ДО назалност - оралност не може се применити на остале фонеме - оне које нису назалне или оралне прекидне звучне фонеме;

б) постоји, према томе, следећа хијерархија обележја: изнад ДО назалност - оралност, морају се наћи ДО прекидност - непрекидност и звучност - безвучност.

(2) Д. Петровић (2000) опонира преко истог ДО назалне и оралне сонанте, а за остале фонеме оставља празна места (в. табелу 3). То значи следеће:

a) ДО назалност - оралност не може се применити на остале фонеме - оне које нису сонанти;

б) постоји, према томе, следећа хијерархија обележја: изнад ДО назалност - оралност мора се наћи обележје [сонорност], онако како га Д. Петровић схвата.

Хијерархија међу обележјима постиже се и према редоследу којим се одређено обележје наводи у матрици ДО. Д. Петровић (2000) исцрпно и прецизно наводи редослед обележја у бројним матрицама прављеним за српски језик, па се тиме овде нећемо бавити.

Међутим, несумњива предност нелинеарних модела огледа се у могућности да се „чворна места”, из којих полази гранање ка хијерархијски нижим обележјима, налазе у различитим редовима. Управо због такве структуре могућа су преклапања различитих обележја и протезања обележја на више сегмената.

1.5. Модел Н. Г. Клементса и Е. Хјум служи да се њиме обједини опис консонанта и вокоида (вокали и глајдови). Утемељен је на претпоставци да било који сегмент произведен у усној дупљи има карактеристичну препреку дефинисану преко два параметра: степен препреке и место препреке (Клементс-Хјум 1996: 203). 


\section{2. Начин артикулације}

2.1. За разлику од места артикулације, које се - бар код гласова који се једноставније творе - релативно лако дефинише, под начином артикулације се подразумевају веома различити појмови. У раду који се бави консонантима српског језика из терминолошког угла ${ }^{5}$ анализирали смо бројне домаће и стране радове (од уџбеника и приручника до енциклопедија и терминолошких речника) и закључили смо да се под начином артикулације обухватају:

1. веома различити артикулациони параметри (положај меког непца, тип препреке, централизованост препреке, степен апертуре);

2. само они параметри који се обично именују као тип (врста) или природа препреке.

2.2. Прва, шира, употреба овог појма може се применити на класификовање свих гласова, па чак и на поделу на главне класе, као што су вокали, сонанти и опструенти, односно вокали и консонанти. Друга, ужа, употреба односи се скоро увек само на ужу класификацију опструената на експлозиве, фрикативе и африкате.

У овом раду под начином артикулације подразумевамо ширу употребу тог појма, али из њега издвајамо обележја која се односе на главне класе. Према томе, у начинска обележја у овом раду издвајамо следећа: [континуираност], [одложено уклањање], [стридентност], [назалност] и [латералност].

\section{3. Континуираност}

\section{1. Артикулациони и акустички план}

3.1.1. На артикулационом плану Р. Јакобсон, М Хале и Г. Фант описују прекидне ${ }^{7}$ гласове као оне који имају потпуну преграду, праћену уклањањем. Фрикативе ${ }^{8}$ описују као гласове који немају потпуну преграду, већ сужење, које значајно умањује утицај резонантних шупљина иза места изговора (ПСА: 22).

3.1.2. Д. Петровић наводи да се „континуираност [...] остварује као непрекинути шум који се појављује као последица сужења говорног тракта кроз који се ваздушна маса пробија тарући се о зидове резонатораํ. Неконти-

\footnotetext{
${ }^{5}$ Више о овој проблематици в. Батас 2005.

${ }^{6}$ Покушали смо, када год је то било могуће урадити, раздвојити артикулациони од акустичког плана.

${ }^{7}$ У радовима на енглеском језику термин су „stops” или „interrupted”, који се ретко у домаћим радовима употребљавају, а кад се употребе, преводе се као „прекидни или зауставни гласови". Овим појмом обухватају се експлозиви и назали.

${ }^{8}$ У ПСА термин је „constrictive”, што је синоним термину „фрикатив”.

9 До данас је у домаћим радовима остао опис да се ваздушна струја таре о зидове теснаца, због чега су се у прошлости фрикативи називали и треним или трљаним гласовима (за више о терминима в. Батас 2005).
} 
нуиране фонеме, с друге стране, карактерише потпуни прекид тока ваздушне масе и нагло отварање преграде праћене праском ослобођене ваздушне масе" (Петровић 2010: 795).

3.1.3. Н. Чомски и М. Хале описују континуиране гласове као оне код којих примарна препрека у вокалском тракту није толико уска да се њоме блокира ваздушна струја; код прекидних гласова ваздушна струја која пролази кроз усну дупљу потпуно је блокирана (СПЕ: 317). Сличан опис дају и Хејз 2009: 78, Оден 2013: 55-56.

3.1.4. М. Хале и Н. Клементс дефинишу континуиране гласове као оне који се формирају са конфигурацијом вокалног тракта која дозвољава ваздушној струји да прође кроз уздужну (мидсагиталну) регију оралног тракта (Хале-Клементс 1983: 7). Њихову дефиницију користи и Хол 2007: 319.

3.1.5. На акустичком плану нагли (абруптни) наступ одваја прекидне од континуираних консонаната, код којих је градуелан. На спектрограмима се код експлозива види оштра вертикална линија којој претходи пауза, праћена звучном линијом (гредом) код звучних гласова (ПСА: 21)

3.1.6. Д. Петровић прекидне (неконтинуиране) такође на акустичком плану описује као гласове код којих се на спектрограмима јавља изразита белина, док тврди да се „[о]бележје континуираности [...] одређује као благ прелаз између претходног гласа и тзв. зоне тишине” (Петровић 2010: 795). Други део описа, везан за [континуираност], могао би се прецизније одредити као појављивање континуираног (непрекинутог) шума дуж целог трајања сегмента на спектрограмима.

\section{2. Употреба у матрицама ДО за српски језик}

3.2.1. Следећом табелом дајемо кратак преглед обележја [континуираност] у матрицама неколико радова: Јакобсон 1949/1964, Брозовић 1968 и 1971, Кристал s.a., Петровић (2000, 2010), Барић at al. 1997. 


\begin{tabular}{|c|c|c|c|c|c|c|}
\hline 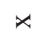 & + & + & + & + & + & + \\
\hline$\exists$ & + & + & + & + & + & + \\
\hline 决 & + & + & + & + & + & + \\
\hline 0 & + & + & + & + & + & + \\
\hline$m$ & + & + & + & + & + & + \\
\hline$\theta$ & + & + & + & + & + & + \\
\hline$F$ & $H$ & 1 & 1 & I & I & I \\
\hline$\exists$ & $H$ & I & 1 & । & I & I \\
\hline 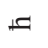 & । & 1 & 1 & । & 1 & 1 \\
\hline 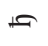 & I & 1 & 1 & । & I & 1 \\
\hline$\exists$ & $H$ & 1 & 1 & । & I & 1 \\
\hline$y$ & I & 1 & 1 & I & I & 1 \\
\hline H & $I$ & 1 & 1 & । & । & 1 \\
\hline$H$ & 1 & I & 1 & I & । & I \\
\hline$F$ & 1 & 1 & I & I & । & 1 \\
\hline 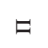 & । & 1 & 1 & । & 1 & 1 \\
\hline 10 & । & 1 & 1 & । & 1 & 1 \\
\hline$\infty$ & + & + & & + & + & 0 \\
\hline$\rightarrow$ & & & & + & + & 0 \\
\hline A & + & + & + & + & 0 & + \\
\hline 5 & + & + & + & + & + & + \\
\hline e & I & 1 & 1 & + & 1 & 1 \\
\hline$\oplus$ & & & & ๙. & 0 & 0 \\
\hline \pm & & & & । & 0 & 0 \\
\hline \multirow[t]{2}{*}{$\Sigma$} & & & & । & 0 & 0 \\
\hline & 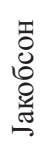 & 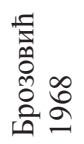 & 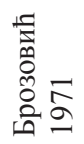 & 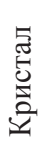 & $\begin{array}{l}\text { 를 } \\
\text { 总 } \\
\stackrel{0}{0} \\
\stackrel{0}{0}\end{array}$ & 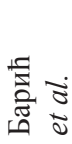 \\
\hline
\end{tabular}


3.2.2. Вокали су изостављени из табеле зато што им се у свим радовима редовно приписује обележје [+континуираност]. Не рачунајући изостављање „минуса” за фонему /g/, које је грешком настало у матрици ДО за српски језик Р. Јакобсона, свуда се експлозиви дефинишу обележјем [-континуираност] и тиме недвосмислено опонирају фрикативима, које карактерише обележје [+континуираност].

3.2.3. С изузетком Р. Јакобсона, који африкатама приписује ДО [ \pm континуираност] (a /ć/ и /d/ ${ }^{10}$ третира као експлозиве), оне се сврставају у групу заједно са експлозивима ДО [-континуираност].

3.2.4. Назалима се једино у примеру матрице ДО за српски језик код Д. Кристала (Кристал s.a.) приписује обележје [-континуираност]. У осталим радовима се или не даје никакво обележје или им се приписују „нуле” (Петровић 2000 и Барић et al. 1997). Ова је пракса у страним радовима напуштена још од традиционалних радова из генеративне фонологије (СПЕ). У њима се [континуираност] дефинише само на основу оног крака ваздушне струје који пролази кроз усну дупљу (в. т. 3.1.3.). При артикулацији назала управо тај крак ваздушне струје наилази на исти тип препреке - потпуну препреку (преграду) - какав се јавља код експлозива.

3.2.5. У ПСА ликвиде су јасно подељене на оне попут фонеме /1/, којој се приписује ДО [+континуираност], од оних попут вибранта /r/, којем се, без обзира на то да ли је лингвални (апикални) или увуларни, приписује [-континуираност] (ПСА: 22). На овај начин их, с изузетком матрице ДО код Кристала s.a., посматрају и у осталим матрицама ДО за српски језик.

Чомски и Хале (СПЕ: 318) тврде да је вибрација врха језика секундарни ефекат сужења шупљине без правог блокирања ваздушне струје ${ }^{11}$. Због тога сматрају да се фонеми /r/ пре може приписати обележје [+континуираност]. Што се тиче пак фонеме /1/, тврде да се може сматрати и континуираном (континуантом), ако се [+континуираност] дефинише као потпуно блокирање ваздушне струје, и неконтинуираном, ако се [-континуираност] дефинише као блокирање ваздушног тока након примарне препреке (idem).

За М. Халеа и Н. Клементса нема дилеме да се латералима приписује [-континуираност], због уздужне (мидсагиталне) регије оралног тракта, која је укључена у дефиницију овог обележја (Хале-Клементс 1983: 7). Поред ових решења, ликвиде је могуће опонирати и према обележју [латералност] (в. т. 7).

\footnotetext{
${ }^{10}$ Пошто се бавимо обележјима која или први пут употребљавају у матрицама обележја за српски језик или која се редефинишу у складу са новијим фонолошким приступима, определили смо се да користимо за фонеме латинично писмо уместо IPA (Међународног фонетског писма) да бисмо избегли било какав вид забуне.

${ }_{11}$ „Вибрација врха језика, међутим, дешава се због пада ваздушног притиска који настаје унутар пролаза између врха језика и палатума када ваздух брзо протекне кроз тај пролаз (Бернулијев ефекат)". (СПЕ: 318; наш превод)
} 


\section{4. Одложено (постепено) уклањање}

\section{1. Артикулациони и акустички план}

4.1.1. Ово обележје први пут у систем обележја уводе Н. Чомски и М. Хале (СПЕ: 318-319). Одмах истичу да ово обележје утиче само на гласове произведене са преградом у усној дупљи. У основи, тврде они, два су начина на који се препрека у вокалном тракту може уклонити: или одједном, што се дешава код експлозива, или одложено (постепено), што се дешава код африката (idem). На акустичком плану Чомски и Хале доводе ово обележје у везу са генерисањем турбуленције у вокалном тракту (idem).

4.1.2. П. Ладефогед оштро критикује дефиницију овог обележја у СПЕ. Тврди следеће: „зато што не узимају у обзир фрикативни шум као дефинишући атрибут конкретног обележја, Чомски и Хале морају да спецификују африкате на други начин. Они то раде додавањем обележја одложеног уклањања примарне преграде. Опозицију одложено према неодложено уклањање примењују само на неназалне прекидне гласове. На основу горецитиране дефиниције, могло би се претпоставити да сви други гласови могу бити спецификовани као они који имају неодложено уклањање" (Ладефогед 1971: 106; наш превод). Затим, наставља у истом тону да тврди да су одбијањем да уведу фрикативни шум као компоненту, приморани да наведу да сви континуирани гласови имају [+одложено уклањање] (idem). Ладефогед уместо обележја континуираност и одложено уклањање предлаже обележја прекидност (заустављања) и фрикативност.

4.1.3. Описујући ово обележје, Б. Хејз тврди да су експлозиви, гласови са обележјем [-одложено уклањање], типични прекидни гласови, а да то нису ни африкате ни назали (Хејз 2009: 79). Реч „одложено” односи се на период полупрепреке за време којег се произведе фрикативни шум, па се у фонетску дефиницију овог обележја може укључити критеријум „фрикативни шум” (idem). Слично и Оден описује ово обележје прецизирајући да је отпуштање потпуне препреке успорено тако да се формира фрикатив након прекидне фазе у артикулацији (Оден 2013: 55). Другим речима, и Хејз и Оден под „одложеним уклањањем” заправо подразумевају „стварање фрикативног шума”. Узевши у обзир системе африката у различитим језицима, Оден сматра да у фонологији до сада није дата њихова репрезентација на задовољавајући начин (Оден 2013: 56).

\section{2. Употреба у матрицама ДО за српски језик}

4.2.1. У србистичким радовима се обележје [одложено уклањање] не користи, али зато Р. Симић и Б. Остојић, слично П. Ладефогеду (1971), предлажу обележје [абруптност] и [турбулентност], при чему је једино различито терминолошко решење. Прво од њих приписују експлозивима и африкатама, а друго фрикативима и африкатама (Симић-Остојић 1996). 
4.2.2. Пошто се ово обележје у домаћим радовима не користи, намеће се питање како се онда у матрицама одвајају африкате од експлозива (више о томе в. т. 5).

\section{5. Стридентност}

\section{1. Артикулациони и акустички план}

5.1.1. Од првих радова (ПСА: 23-24), па све до савремених (Хејз 2009: $85)$ артикулационе и акустичке карактеристике овог обележја непрецизно се дефинишу. На акустичком плану Р. Јакобсон, М. Хале и Г. Фант описују стридентне гласове као оне које имају ирегуларни осцилограм. Непрецизност овог описа огледа се у следећем: с једне стране, ирегуларни образац осцилограма присутан је код свих непериодичних гласова, а посебно је уочљив код безвучних фрикатива и африката, док је, с друге стране, одређена врста правилности (периодичности) везана за све звучне фрикативе и африкате због присутног тона произведеног на гласним жицама.

5.1.2. На спектрограмима описују изглед стридентних гласова као хаотичан, док за благе гласове тврде да их одликује нешто правилнији распоред шума (ПСА: 23, а слично и Петровић 2000). Хаотичан изглед шума везује се за све турбулентне гласове, пошто је турбуленција, поједностављено речено, управо хаотично, непредвидиво, кретање честица. На спектрограмима фрикатива и африката могу се уочити одређени појасеви где је шум концентрисанији и подсећају на резонантне појасеве (форманте) код вокала.

5.1.3. Према Јакобсону, Халеу и Фанту, јак турбулентни шум је последица комплексније препреке (ПСА: 24; наше истицање). У наставку прецизирају да је додатна баријера, којом се повећава отпор ваздушној струји, неопходна за артикулацију стридентних гласова (а могу је стварати усне, зуби или увула) (idem). Због тога се фонеме са обележјем [стридентност] називају још и фонеме „са оштрим ивицама”, наспрам оних „са глатким ивицама” (Петровић 2000: 796, Муљачић 1964). У савременим истраживањима познато је да се (турбулентни) шум по изласку из сужења (теснаца) додатно разбија, најчешће о секутиће, и због тога бива додатно појачан.

5.1.4. Према Чомском и Халеу, стридентне гласове акустички карактерише јачи шум него нестридентне парове. Турбуленција се ствара у зависности од природе површине, брзине тока и угла под којим ваздушна струја удара о површину. Што је храпавија површина, што је бржи ток струје и што је угао упада ближи деведесет степени, то ће стридентност бити израженија (СПЕ: 329).

\section{2. Употреба у матрищама ДО за српски језик}

5.2.1. Следећом табелом дајемо кратак преглед обележја [континуираност] у матрицама неколико радова: Јакобсон 1949/1964, Брозовић 1968 и 1971, Кристал s.a., Петровић 2000 и 2010, Барић at al. 1997. 


\begin{tabular}{|c|c|c|c|c|c|c|}
\hline$\star x$ & & & & 1 & 1 & 1 \\
\hline$\exists$ & & & & 1 & + & + \\
\hline 不 & & & & 1 & + & 0 \\
\hline 0 & & & & + & 0 & 0 \\
\hline$m$ & & & & + & 0 & 0 \\
\hline$\theta$ & & & & + & 0 & 0 \\
\hline$\sigma$ & & + & + & I & + & + \\
\hline$\Rightarrow$ & & + & + & 1 & + & + \\
\hline 上 & & 1 & 1 & + & 1 & 1 \\
\hline 上 & & 1 & 1 & + & 1 & 1 \\
\hline$\exists$ & & + & + & + & + & + \\
\hline$\check{z}$ & & & & I & 1 & 0 \\
\hline H & & & & । & 1 & 0 \\
\hline$H$ & & I & I & I & 1 & 0 \\
\hline$F$ & & 1 & 1 & 1 & 1 & 0 \\
\hline E & & & & । & 1 & 0 \\
\hline 10 & & & & 1 & 1 & 0 \\
\hline$\infty$ & & & & + & 0 & 0 \\
\hline$\rightarrow$ & & & & + & 1 & 0 \\
\hline$A$ & & & & a. & & 0 \\
\hline 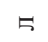 & & & & 1 & & 0 \\
\hline 2 & & & & I & & 0 \\
\hline 由 & & & & $\sigma$. & & 0 \\
\hline \pm & & & & 1 & & 0 \\
\hline$\Sigma$ & & & & 1 & & 0 \\
\hline & 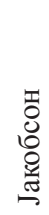 & 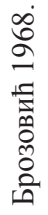 & 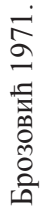 & 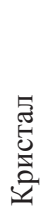 & 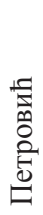 & 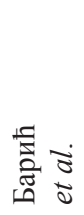 \\
\hline
\end{tabular}


5.2.2. Пре него што пређемо на анализу матрица ДО за српски језик, осврнућемо се укратко на различите употребе овог ДО у студијама ${ }^{12}$. Постоје студије у којима се све африкате сматрају прекидним стридентним фонемама (ПСА: 24, Клементс 1999). Г. Н. Клементс сматра да се прекидне фонеме (експлозиви и африкате) супротстављају фрикативима помоћу обележја [-контиуираност], а да се потом африкате супротстављају експлозивима помоћу обележја [+стридентност]. У оваквом приступу нејасно место заузимају нестридентне африкате. Фонолози се не слажу ни око тога да је стридентност независно обележје од места артикулације или се пак везује само за короналне фонеме ${ }^{13}$, као што је то случај код Хејза (2009: 85).

5.2.3. Р. Јакобсон и Р. Симић и Б. Остојић не користе ово обележје у матрицама за српски језик. Остали га употребљавају, али нико од њих на начин на који је то урађено у Клементс (1999) (в. т. 5.2.2). Д. Брозовић (1968, $1971)$, Д. Петровић $(2000,2010)$ и Е. Барић et al. (1997) уједначено ${ }^{14}$ користе обележје да њиме раздвоје „тврде” од „меких” африката, па ће дентална и палато-алвеоларне африкате имати обележје [+стридентност], а алевопалаталне палатализоване [-стридентност] (више о расправи о овом питању в. Батас 2018).

5.2.3. Што се тиче експлозива, Д. Брозовић једино денталне експлозиве ([-стридентност]) опонира денталној африкати, која има [+стридентност]. Код Д. Кристала и Д. Петровића сви експлозиви имају обележје [-стридентност], а код Е. Барић имају „нуле”.

5.2.4. Што се тиче пак фрикатива ${ }^{15}$, у матрици код Д. Кристала /f/, /s/, /z/ опонирају /š/, /ž/, /h/ (уз /j/ и /v/). Прве од њих имају обележје [+стридентност]. На основу тога претпостављамо да су у поменутој матрици ДО за српски језик [стридентност] и [сибилантност] узети као синоними. За Е. Барић et al. (1997) међу фрикативима опонирају по овом обележју само /š/ и /h/ (први од њих [+стридентност]).

\footnotetext{
${ }^{12}$ Нејасно је и да ли је стридентност исто што и сибилантност у радовима као што Ладефогед 1971.

${ }^{13}$ В. детаљну расправу о овом проблему у Хол 2007: 321.

${ }^{14}$ Вероватно је тако урађено и у матрици ДО за српски језик код Д. Кристала (s.a), али постоји извесна недоследност у употреби симбола IPA (Међународног фонетског писма), па сматрамо да се у томе крије сврставање денталне (традиционално „тврде”) са алвео-палаталним палатализованим (традиционално „меким”) африкатама.

15 За Петровића и Кристала су и /v/ и /j/ фрикативи. У матрици код Д. Кристала обе фонеме имају [+стриденетност], док Д. Петровић фонему /j/ и /h/ опонира фонемама $/ \check{\mathrm{s}} /$ и / $/$ / (потоње имају [+стриденетност]).
} 


\section{6. Назалност}

\section{1. Артикулациони и акустички план}

6.1.1. Артикулационе карактеристике назалних фонема уједначено су описане у свим релевантним радовима. На артикулационом плану за ово обележје подразумева се спуштање задњег (меког) непца или велума и пролаз ваздушне струје кроз усну и кроз носну дупљу. У усној дупљи се формира преграда при артикулацији назалних сонаната. Јакобсон, Хале и Фант назалне сонанте сврставају у јединствену групу прекидних фонема, заједно са експлозивима (ПСА: 40, а слично је и код Ладефогеда (1971: 105)).

6.1.2. Акустичке карактеристике назалних вокала најдетаљније су изложене у ПСА. Јакобсон, Хале и Фант истичу да је на спектрима назалних вокала уочљива већа густина форманата него што је то случај код одговарајућих оралних фонема, а затим прецизирају да се најчешће између првог и другог форманта појављује додатни назални формант, што доводи до слабљења јачине прва два орална форманта (ПСА: 39).

6.1.3. За назалне сонанте тврде да их од супротстављених оралних експлозива (m/:/b/, /n/:/d/) разликује назални призвук ${ }^{16}$ за време оклузије. Тај назални призвук одликују два јасна форманта: један на око 200 херца, а других на око 2500 херца (ibid.: 40). Додатни „врхунци и нуле” немају никаквог утицаја на друга резонантна обележја (idem).

6.1.4. После бројних испитивања акустичких карактеристика назала, данас се на њихову акустичку природу гледа другачије. Представљено у најкраћим цртама, карактерише их: први формант (слично као у ПСА), који је ниске фреквенције, затим нижи интензитет, а шири појас форманата, као и присуство антиформаната на спектру. Управо су антиформанти у корелацији са местом артикулације назала (више о овој проблематици в. Риц-Јонгман 2009: 194-197), док висина назалних форманта зависи од анатомских карактеристика носне дупље и нема за лингвистику никаквог значаја (idem).

\section{2. Употреба у матрицама ДО за српски језик}

6.2.2. Следећом табелом представљамо обележје [назалност] у матрицама ДО за српски језик. Овај пут је табела проширена и решењима Р. Симића и Б. Остојића (1996).

${ }^{16}$ Nasal murmur (енгл.) 


\begin{tabular}{|c|c|c|c|c|c|c|c|}
\hline$\rtimes$ & & & & I & & & 0 \\
\hline$\exists$ & & & + & I & & & 0 \\
\hline$\check{x}$ & & & + & I & & & 0 \\
\hline 0 & & & & 1 & & & 0 \\
\hline$m$ & & & & 1 & & & 0 \\
\hline$\theta$ & & & & 1 & & & 0 \\
\hline$\sigma$ & & & + & 1 & & & 0 \\
\hline$\exists$ & & & + & 1 & & & 0 \\
\hline 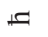 & & & + & 1 & & & 0 \\
\hline L & 1 & & + & 1 & & & 0 \\
\hline$\exists$ & & & & 1 & & & 0 \\
\hline 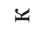 & & & & I & & & 0 \\
\hline$H$ & & & & 1 & & & 0 \\
\hline$H$ & & & & I & & & 0 \\
\hline$F$ & 1 & & & 1 & & & 0 \\
\hline$\exists$ & & & & 1 & & & 0 \\
\hline 0 & 1 & & & 1 & & & 1 \\
\hline$\infty$ & & & & 1 & & I & I \\
\hline$\rightarrow$ & & & & 1 & & I & 0 \\
\hline 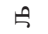 & & I & I & 1 & 1 & I & 1 \\
\hline$\curvearrowleft$ & & I & 1 & 1 & 1 & 1 & 1 \\
\hline 2 & & 1 & 1 & 1 & 1 & I & 1 \\
\hline$\oplus$ & + & + & + & + & + & + & + \\
\hline \pm & + & + & + & + & + & + & + \\
\hline$\Sigma$ & + & + & + & + & + & + & + \\
\hline & 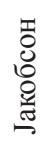 & 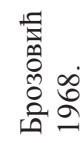 & 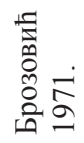 & 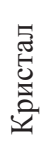 & 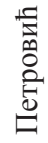 & U & 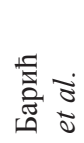 \\
\hline
\end{tabular}


6.2.2. Заједничко свим матрицама ДО јесте да се фонемама $/ \mathrm{m} /, / \mathrm{n} /$ и $/ \mathrm{nj} /$ приписује обележје [+назалност]. Међутим, значајно се матрице међусобно разликују када су у питању фонеме које опонирају назалима преко овог обележја. Р. Јакобсон супротставља их експлозивима (/d/ сматра експлозивом), јер схвата назалне консонанте као неконтинуиране прекидне назале (ПСА), па су тако супротстављени: $/ \mathrm{m} /:$ /b/, /n/ : /d/ и /nj/ : /d/. Д. Брозовић ${ }^{17}$ и Д. Петровић $(2000,2010)$ супротстављају их ликвидама. Р. Симић и Б. Остојић (1996) супротстављају ова три назала осталим сонантима (ламинарима), док ce у Е. Барић et al. 1997 назали супростављају и ликвидама и звучним лабијалним фонемама.

\section{7. Латералност}

\section{1. Артикулациони и акустички план}

7.1. Ни ово обележје, као ни одложено уклањање, не налази се на списку обележја Р. Јакобсона (ни у ПСА, ни у другим радовима). Њега уводе у систем обележја Н. Чомски и М. Хале и ограничавају га само за короналне гласове. Дефинишу га на артикулационом плану спуштањем обе или једне стране језика, што омогућава ваздушној струји да прође у близини кутњака (СПЕ: 317).

7.2. П. Ладефогед супротставља гласове код којих ваздух пролази са стране (латералне) онима код којих ваздух пролази средишњим делом (централне) (Ладефогед 1971: 46).

7.3. Акустичке карактеристике латерала сличне су карактеристикама назала, будући да се у акустичкој структури могу наћи и форманти и антиформанти. Први формант у српском језику налази се на око 1100 херца за мушке гласова, а на око 1200 херца за женске; други формант налази се на око 2500 херца и код мушких и код женских гласова (Батас 2014).

\section{2. Употреба у матрицама ДО за српски језик}

7.2.1. Хол (2007) цитира бројне радове који показују да је ово обележје неопходно да би се њиме анализирао контраст између /1/ и /r/. Као што смо већ видели у т. 3.2.5, у ПСА контраст међу овим фонемама остварују се [+континуираност] за /1/, односно [-континуираност] за /r/ (ПСА: 22). Међутим, у скоријим радовима латерали почињу да се сагледавају као фонеме са обележјем [-континуираност], док је статус вибраната такође нејасан, па их, на пример, поједини фонолози третирају као сегменте са обележјем [+континуираност] (СПЕ: 318, Хале-Клементс 1983: 7).

7.2.2. До сада ово обележје није коришћено у српском језику.

\footnotetext{
${ }^{17}$ Код Брозовића (1971) поткрала се у табели грешка, па су случајно (прет)палаталне африкате и фрикативи добили ДО [+назалност] уместо [+акутност].
} 


\section{8. Закључна разматрања}

8.1. На крају ћемо начинска обележја анализирати из угла класа африката, назала и ликвида. Да бисмо представили матрицу обележја за српски језик, недостају детаљно размотрена обележја „главних класа”, што ће бити тема следећег рада.

\section{2. Фрикативи - експлозиви - африкате}

У табелама 4-6 износимо три начина на који се могу међусобно опонирати фрикативи, експлозиви и африкате. У првој се од њих (табела 4) види да се фрикативи супротстављају експлозивима и африкатама преко обележја [+континуираност], док се експлозиви и африкате међусобно разликују на основу обележја [одложено уклањање]. Ова табела је најсличнија приступу изнетом у СПЕ. Од тог проступа га разликује, ако усвојимо критику П. Ладефогеда (1971), дефинисање обележја [одложено уклањање], које би се могло схватити као стварање сужења на артикулационом плану, односно формирање фрикативног (турбулентног) шума на акустичком плану, што чине Хејз (2009) и Оден (2013).

Табела 4

\begin{tabular}{|l|c|c|c|}
\hline & Фрикативи & Експлозиви & Африкате \\
\hline Континуираност & + & - & - \\
\hline Одложено уклањање & + & - & + \\
\hline
\end{tabular}

Следећом табелом настојимо да избегнемо редефинисање обележја [одложено уклањање]. Ако се фрикативима додели „нула” за дато обележје, то онда значи да се само прекидни сегменти могу опонирати по датом обележју.

\section{Табела 5}

\begin{tabular}{|l|c|c|c|}
\hline & Фрикативи & Експлозиви & Африкате \\
\hline Континуираност & + & - & - \\
\hline Одложено уклањање & 0 & - & + \\
\hline
\end{tabular}

Последња табела се заснива на приступу који предлаже Клементс (1999). Резултат је исти као у табели 4, али се уместо [одложеног уклањања] јавља обележје [стридентност]. Тиме се превазилази потешкоћа да се фрикативи дефинишу као сегменти код којих се преграда постепено уклања. У овом приступу не проналази се решење за нестридентне африкате. 
Табела 6

\begin{tabular}{|l|c|c|c|}
\hline & Фрикативи & Експлозиви & Африкате \\
\hline Континуираност & + & - & - \\
\hline Стридентност & + & - & + \\
\hline
\end{tabular}

\section{3. Назали}

У наредним табелама приказано је како назални сонанти опонирају обележјем [назалност] са експлозивима (табела 7) и са оралним сонантима или само са ликвидама (табела 8). Први приступ могућ је ако се сонанти не третирају као јединствена класа гласова, док други очигледно почива на претпоставци да је назале, ликвиде и глајдове могуће објединити једним обележјем, које их раздваја од вокала и опструената. Пошто се у овом раду не бавимо обележјима главних гласа, изоставићемо даљу дискусију о обележјима [сонорност], [апроксимантност] и [консонантност]. А како се у раду нисмо бавили ни хијерархијом обележја, изостављамо и расправу о томе да ли је назалност привативно обележје и да ли је везано директно за корен, што предлажу, на пример, Клементс-Хјум 1995.

\section{Табела 7}

\begin{tabular}{|l|c|c|}
\hline & Назали & Експлозиви \\
\hline Континуираност & - & - \\
\hline Назалност & + & - \\
\hline
\end{tabular}

Табела 8

\begin{tabular}{|l|c|c|}
\hline & Назали & Орални сонанти (или само ликвиде) \\
\hline Назалност & + & - \\
\hline
\end{tabular}

\section{4. Ликвиде}

На крају ћемо размотрити још једном однос између ликвида. У табели 9 налази се обележје [континуираност] онако како је употребљено у србистичким радовима. У друге две табеле налазе се новије интерпретације овог обележја. У табели 10 се фонеме $/ 1, \mathrm{lj} /$, супротно претходном решењу, сматрају неконтинуираним, док у последњој табели опозиција међу ликвидама почива на обележју [латералност]. 
Табела 9

\begin{tabular}{|l|c|c|}
\hline & $/ \mathrm{r} /$ & $/ 1, \mathrm{lj} /$ \\
\hline Континуираност & - & + \\
\hline
\end{tabular}

Табела 10

\begin{tabular}{|l|c|c|}
\hline & $/ \mathrm{r} /$ & $/ 1, \mathrm{j} /$ \\
\hline Континуираност & + & - \\
\hline
\end{tabular}

Табела 11

\begin{tabular}{|l|c|c|}
\hline & $/ \mathrm{r} /$ & $/ 1,1 \mathrm{j} /$ \\
\hline Латералност & - & + \\
\hline
\end{tabular}

\section{ЛИТЕРАТУРА}

Барић et al. 1997: Eugenija Barić et al., Hrvatska gramatika. Zagreb: Školska knjiga.

Батас 2005: Ана Батас, „Класификација консонаната српског језика са становишта артикулационе фонетике - терминолошки аспект", Научни састанак слависта у Вукове дане, 34/3, 113-137.

Батас 2014: Ана Батас, Фонетске и акиенатске промене речи у континуалном говору. Необјављен рукопис докторске дисертације. Београд: Филолошки факулет.

Батас 2018: Ана Батас, „Обележје короналност у српском језику”, Научни састанак слависта у Вукове дане, 47/3, 5-19.

Брозовић 1968: Dalibor Brozović, „O fonološkom sustavu suvremenog standardnog hrvatskosrpskog jezika", Radovi Filozofskog fakulteta u Zadru. Razdio lingvističko-filološki, 7, Zadar: Filozofski fakultet u Zadru, 20-39.

Брозовић 1971: Dalibor Brozović, „O alofonskoj problematici u hrvatskoj ortoepiji”, Radovi Filozofskog fakulteta u Zadru. Razdio lingvističko-filološki, 10/9, Zadar: Filozofski fakultet u Zadru, 5-29.

Бурсма 1998: Paul Boersma, Functional Phonology [LOT International Series 11]. The Hague: Holland Academic Graphics, [Doctoral thesis, University of Amsterdam].

Јакобсон 1949/1964: Roman Jakobson, Selected Writings I. The Hague: Mouton.

Клементс 1999: G. N. Clements, „Affricates as noncontoured stops”, [in:] Osamu Fujimura, Brian D. Joseph, and Bohumil Palek (eds.), Proceedings of 
LP '98: Item Order in Language and Speech. Prague: The Karolinum Press, 271-299.

Клементс-Хјум 1996: G. N. Clements, Elizabeth V. Hume, „The internal organization of speech sounds", [in:] John A. Goldsmith (ed.) The Handbook of Phonological Theory. Blackwell Publishing.

Кристал s.a.: Dejvid Kristal, Kembrička enciklopedija jezika. (red. R. Bugarski), Beograd: Nolit.

Ладефогед 1971: Peter Ladefoged, Preliminaries to Linguistic Phonetics. Chicago, London: The University of Chicago Press.

Муљачић 1964: Žarko Muljačić, Opća fonologija i fonologija suvremenog talijanskog jezika. Zagreb: Sveučilište u Zagrebu.

Оден 2013: David Odden, Introducing Phonology. $2^{\text {nd }}$ Edition. New York: Cambridge University Press [2005].

Петровић - Гудурић 2010: Драгољуб Петровић, Снежана Гудурић, Фонологија српскога језика. Београд: Институт за српски језик САНУ, Београдска књига, Матица српска.

Петровић 2000: Драгољуб Петровић, „О репертоару ИДО у фонолошком систему стандарднога српског језика", Јужнословенски филолог, LVI, 789-802.

ПCA: Roman Jakobson, Gunnar Fant, Morris Halle, Preliminaries to Speech Analysis: The Distinctive Features and Their Correlates. $2^{\text {nd }}$ edition. MIT, Acoustics Lab., Technical Report No. 13, 1963 [1952].

Риц-Јонгман 2009: Henning Reetz, Allard Jongman, Phonetics: Transcription, Production, Acoustics, and Perception. Blackwell textbooks in linguistics, 22, Wiley-Blackwell.

Симић - Остојић 1996: Радоје Симић и Бранислав Остојић, Основи фонологије српског књижевног језика. Београд: Универзитет у Београд.

CIE: Noam Chomsky, Morris Halle, The Sound Pattern of English. New York, Evanston, and London: Harper \& Row, 1968.

Tраск 1996: R. L. Trask, A Dictionary of Phonetics and Phonology. London, New York: Routledge.

Флеминг 2002: Edward S. Flemming, Auditory Representations in Phonology. New York, London: Routledge.

Хале-Клементс 1983: Morris Halle, G. N. Clements, Problem Book in Phonology: A Workbook for Introductory Courses in Linguistics and in Modern Phonology. Cambridge, Massachusetts, London, England: The MIT Press.

Xej3 2009: Bruce Hayes, Introductory Phonology. Wiley-Blackwell.

Хол 2007: Т. A. Hall, „The segmental features”, [in:] Paul de Lacy (ed.) The Cambridge Handbook of Phonology. Cambridge University Press, 311-335. 
Ana S. Batas

\section{MANNER FEATURES IN THE SERBIAN LANGUAGE}

\section{Summary}

In this paper the author discusses manner features (the features that specify the manner of articulation) such as [+/-continuant], [+/-delayed release], [+/-strident], [+/-nasal] and [+/-lateral], and their applications in Serbian phonology. 